\title{
Exploration of the Development of Science and Technology in Historical Turbulence: A Review on the Book Series Vortex Dynamics of the Development of Science and Technology
}

\author{
WANG Fang 王芳*
}

(Institute for the History of Natural Sciences, Chinese Academy of Sciences, Beijing 100190, China)

Review of Baturin, Yuri М. [Батурин, Юрий М.], ed. 2018-19. Вихревая динамика развития науки и техники [Vortex Dynamics of the Development of Science and Technology]. 3 vols. 2124 pages. Moscow: ИИЕТ РАН [IHST RAS].

Baturin, Yuri M., ed. 2018. Турбулентная история науки и техники [Turbulent History of Science and Technology]. Vol. 1, Вихревая динамика развития науки и техники: Россия/СССР. Первая половина XX века [Vortex Dynamics of the Development of Science and Technology: Russia/USSR. The First Half of the Twentieth Century]. 567 pages. Moscow: ИИЕТ РАН.

Baturin, Yuri M., ed. 2018. Экстремальный режим развития науки и техники [Extreme Mode of Development of Science and Technology]. Vol. 2, Вихревая динамика развития науки и техники: СССР/Россия. Первая половина ХХ века [Vortex Dynamics of the Development of Science and Technology: USSR/Russia. The First Half of the Twentieth Century]. 721 pages. Moscow: ИИЕТ РАН.

Baturin, Yuri M., ed. 2019. Самоорганизация, турбулентный переход и диссипаиия [SelfOrganization, Turbulent Transition and Dissipation]. Vol. 3, Вихревая динамика развития науки и техники: СССР/Россия. Вторая половина XX века [Vortex Dynamics of the Development of Science and Technology: USSR/Russia. The Second Half of the Twentieth Century]. 836 pages. Moscow: ИИЕТ РАН.

$\mathrm{T}$ The turbulent flow of fluids is very common in nature; examples include rushing rivers, curling smoke, the two white traces left by a plane as it flies overhead, and so on. If history is a flowing river, how should we look upon the development of

Received: November 12, 2021. Revised: November 30, 2021.

This paper is translated from Chinese by Yu Yueyuan 俞月圆, and has been copyedited by John Moffett.

* Research interest: Soviet and Russian history of science and technology, especially aerospace.

Email: wangfang@ihns.ac.cn 
science and technology (S\&T) in historical turbulence? The book series Vortex Dynamics of the Development of Science and Technology (Вихревая динамика развития науки и техники) is an attempt to do just that. When concepts including "turbulence," "eddy," and "Reynolds number," which originally belong to fluid dynamics, are used in the interpretation of history, some familiar historical materials are thus viewed with new perspectives. The authors of the book series have also managed to collect a large amount of material, most of which has never been published before.

As a monograph written collectively by dozens of researchers at the S. I. Vavilov Institute for the History of Science and Technology of the Russian Academy of Sciences (ИИЕТ РАН), Vortex Dynamics of the Development of Science and Technology focuses on examining the history of S\&T in Russia in the twentieth century. The authors avoid viewing history as a simple linear development; rather, they choose to consider policy decisions, international influences, wars, and other factors as "vortexes" or rapids in the long history, trying to demonstrate how historical vortexes were created, how social turbulence (or turmoil) came into being, and how the developmental pattern of S\&T under unbalanced conditions looks like.

How is it possible to describe the history of science using physical terms? Or, more specifically, why was "historical vortex" chosen to be the methodology of the book? The authors provide some explanations in each volume. They argue that for any scientific environment, changes occur not only at the temporal level to its quality and condition, but also at the spatial level to its physical structure-it moves like flowing water. This means that such a process may have the character of a vortex, featuring constant changes in the fluid's structure and the spontaneous creation of a vortex structure. Therefore, the authors hope to produce a historical description for historic situations of various types and scales that is very close to the truth. Of course, they agree that this approximation is subject to their current level of understanding. In addition, Yuri M. Baturin (Юрий М. Батурин, 1949-), editor of this book series, in the 1990s has used a similar methodology to interpret some historical and political events (Baturin and Dobrocheev 1994; Baturin 1991), so the new books could be seen as his attempt to use physics to interpret history on a grander scale.

Certainly, the authors believe that a situation in the historical world is much more complex than that in the physical world, where a correct diagram depicting turbulence can be obtained by three-dimensional observation. The world of history, in contrast, needs to be studied in a multidimensional space. Thus, the authors describe the space of Soviet/Russian science as seven-dimensional, including: (1) subjects (participants) of S\&T activity; (2) modes of S\&T activity, and scientists' (subjects) behavioral and thinking patterns; (3) S\&T stand points of subjects; (4) material products and other achievements produced by the modes adopted in the S\&T activity; (5) intellectual or spiritual products and other non-material achievements; (6) norms (social institutions) that stipulate rules 
for interaction between S\&T professionals in this subspace; (7) organizations that promote or hinder the development of S\&T, and processes that disrupt, integrate, and disintegrate the S\&T spaces. The authors consider turbulence as a natural form of existence in such a mega-system, covering both disruptions or oscillations and some natural self-organizing processes, resulting in temporarily stable (and dissipative) media, namely structures of a physical, social, economic, and intellectual nature.

The three volumes of the book series analyze various mechanisms in the development of S\&T through an abundance of case studies. The first volume, Turbulent History of Science and Technology (Турбулентная история науки и техники), covers the period from the beginning of the twentieth century to the eve of the Second World War and focuses on the development of science. The opening two chapters introduce the rise of "historians of science" and "historians of technology" as academic professionals, the "social turbulence" (социальная турбулентность) approach to conducting historical research, and the context of the twentieth century. Chapter 3 describes the trajectory of science and the fate of scientists as reflected in the First World War and the two revolutions ${ }^{1}$ that happened in the country. This section introduces the Academy of Sciences of the Soviet Union in turbulent times, the first wave of scientific migration, national policies for scientific organizations, and attempts to realize the "symbiosis of science and education" (симбиоз науки и образования). The authors argue that even in the midst of social chaos, some unifying forces in S\&T had their roles to play, such as the establishment of the Council for the Study of Productive Forces under the Academy of Sciences of the Soviet Union, the Leningrad regime and scientific societies, the policy that popularized S\&T, and others. These are the subjects of Chapter 4 . Chapters 5 and 6 describe the development of the exact sciences, natural sciences, and hydraulic engineering technology in different social contexts. Topics of discussion include mathematics, human genetics, earth sciences, social geography, and the construction of hydro projects.

The second volume Extreme Mode of Development of Science and Technology (Экстремальный режим развития науки и техники) focuses on the mid-twentieth century, from industrial preparations prior to the Second World War, the wartime mobilization of S\&T, and the postwar technological take-off of the Soviet Union. In this volume, the authors devote three chapters to the development of different S\&T fields in the Soviet Union, including electrification, chemical industry, aircraft manufacturing, radio technology, rocket technology, computing technology, nuclear energy, mathematics, and evolutionary theory. Chapter 10, "Science, Technics, Nature" (Наука. Техника. Природа), ехаmines environmental issues in the development of science, technology, and craft in the Soviet Union and Russia. The final part of this volume concludes with portraits of scientists and engineers against the historical background.

1 The February Revolution and the October Revolution that erupted in Russia in 1917. 
The third volume, Self-Organization, Turbulent Transition and Dissipation (Самоорганизация, турбулентный переход и диссипация) focuses on the development of S\&T in the second half of the twentieth century. Chapter 13 focuses on the situation of evolutionary theory in the Soviet Union from encountering crisis, reviving thereafter, experiencing prosperity, to encountering the next crisis. Chapters 14 and 15 examine the differences between developments in S\&T due to the impact of "turbulent" external factors, using relativity, mathematics, electronics industry, computing technology, informatics, military aviation, and the aerospace industry used for military purposes as examples. The volume also pays attention to scientific immigration, where the authors describe the formation of Russian academic immigrant groups in the United States. Of particular importance, this section also explores the state policy of science during turbulent times, introduces the personnel policy in the area of S\&T and science popularization policy in the Soviet Union and Russia, as well as the historical experience of the reform of the Russian Academy of Sciences. The final chapter of this volume, Chapter 19, summarizes the methodology of "historical vortex research" (историко-вихревая исследования).

Authors of each chapter note waves of different lengths in the development of their respective research subjects. These waves form cycles of six, twelve, twenty-four, or thirty-six years; the beginnings and ends of these cycles of unequal length coincide at certain points. Based on this, the book concludes with an attempt to describe the temporal waves and cycles at the most macro level. Taking the relationship between science and government into consideration, the authors note that "in general, the entire history of the Soviet Union and Russia's S\&T development in the twentieth century is essentially turbulent. . . . All described waves and phases combine periods of development and stagnation, and are clearly turbulent in nature. Yet in the case of stagnant periods, the socio-political base dominates in turbulence, while in the case of creative breakthroughs, the scientific-technical and industrial-organizational bases dominate." 2 The authors recognize that the waveform of historical development is subject to a certain amount of error, the "uncertainty corridor" (коридор неопределенности) being 4.5 years before or after the date of the event being studied. Nevertheless, whether historical development can be divided into temporal waves and cycles with such precision is something that requires further exploration by historians.

This book series not only reviews the history from the perspective of vortex dynamics, but also explores some of the issues that are of interest to the international

2 “В целом же вся российско-советская история развития науки и техники в XX в. существенно турбулентна. . . . Все описанные волны и фазы сочетают периоды развития и стагнации, носят четко просматривающийся турбулентный характер. Но в случае депрессивных этапов в турбулентности доминирует социально-политическая основа, в случае же созидательных рывков - научно-техническая и промышленно-организационная." 
community studying history of S\&T, presenting many points worth noticing. For example, the second volume recalls with the sentiment of a historian the story of how the first director of the Institute for the History of Science and Technology, Academy of Sciences of the Soviet Union, was wrongfully executed, the institute forced to close, the professional collective of historians of S\&T, which was still in infancy, almost destroyed, and the eventual reestablishment of the institute in November 1944. The institute's tenacity through such historical ups and downs is admirable. In different chapters, the book series introduces the history of the Russian Academy of Sciences, especially its reform, which has attracted much attention lately, exploring the relationships between power and science. It holds that a real reform of the Russian Academy of Sciences must be free from the "state needle" (государственная игла); or in other words, from total dependence on bureaucracy. Space rocket technology is a highlight of Soviet and Russian S\&T. The book presents the rise and development of this important field through the use of extensive archives and detailed data.

In sum, readers from all fields will find topics that are familiar and interesting to them in this extensive examination of the historical development of S\&T from a macro perspective.

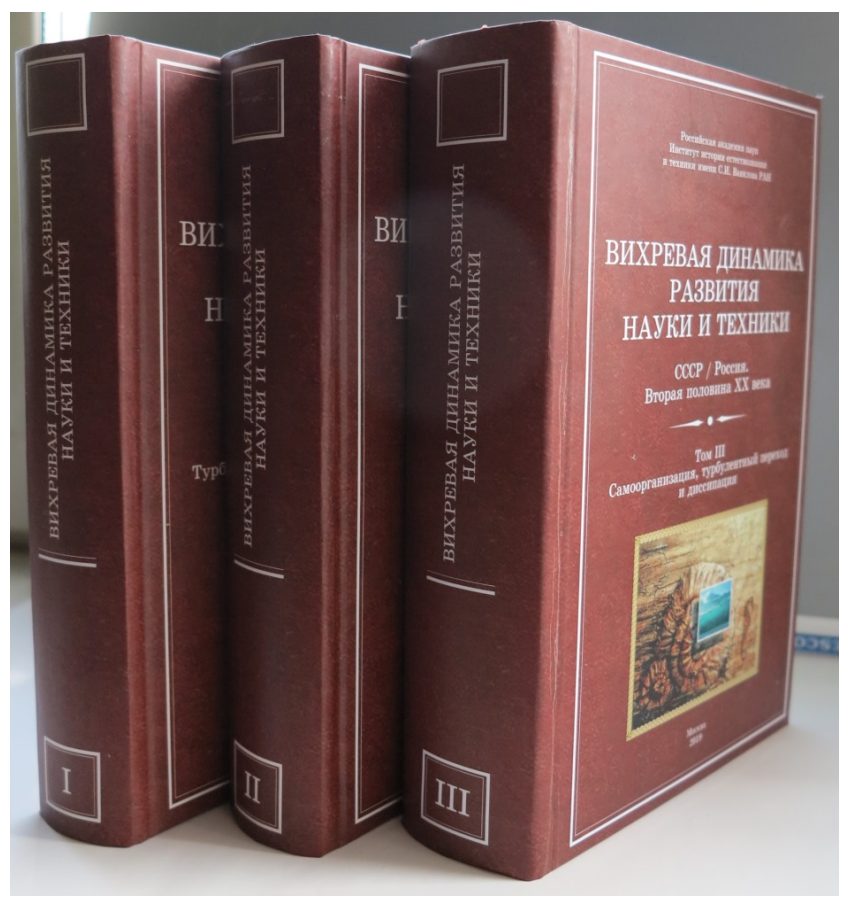

Figure 1: Vortex Dynamics of the Development of Science and Technology. Photo by Yuri Baturin. 


\section{References}

Baturin, Yu. М. [Батурин, Ю. М.]. 1991. “Ледоход истории” [Icebreaker of History]. Сегодня [Today], no. 1, 11-15.

Baturin, Yu. M., and O. V. Dobrocheev [О. В. Доброчеев]. 1994. “История как частный случай физики" [History as a Special Case of Physics]. Столища [Capital], no. 10, 42-43. 